\title{
Analysis of the Seaweed Day Cream Product Buying Intention: Theory of Planned Behavior Approach
}

\author{
Ayulia Karisma Putri \\ Department of Family and Consumer Sciences, \\ Faculty of Human Ecology, \\ Bogor Agricultural University \\ Retnaningsih* \\ Department of Family and Consumer Sciences, \\ Faculty of Human Ecology, \\ Bogor Agricultural University \\ *Corresponding author :retnaningsih_ipb@yahoo.com
}

\begin{abstract}
Seaweed is one of the abundant and widely used marine resources which has been popular as of the basic materials of cosmetics and skin care, such as day cream. The study aimed to analyze the intention to buy seaweed day cream product manufactured by Bogor Agricultural University (IPB) and sold at Serambi Botani, Indonesia, using the Theory of Planned Behavior approach including attitude, subjective norms, and behavioral control. The data were collected from 400 female students of IPB who were selected randomly as participants and the office staffs of Serambi Botani. Students were asked to fill in the structured questionnaire with self-report methods while the staffs were interviewed about the seaweed day cream product. The findings showed the attitude of students toward seaweed day cream product was identified fair, yet the subjective norms and behavioral control were low. Thus, the majority of IPB students was not interested in buying the product.
\end{abstract}

Keywords: attitude, behavioral control, intention to buy, seaweed day cream, subjective norm

\begin{abstract}
Abstrak. Rumput laut merupakan salah satu sumber daya laut yang melimpah dan banyak dimanfaatkan. Salah satu pemanfaatannya yang populer ialah sebagai bahan baku produk kosmetik dan perawatan kulit seperti krim siang hari (day cream). Penelitian ini bertujuan untuk menganalisis minat beli produk day cream berbahan baku rumput laut yang diproduksi oleh Institut Pertanian Bogor (IPB) dan dipasarkan di Serambi Botani, Indonesia, menggunakan pendekatan Theory of Planned Behavior (TPB) yang meliputi aspek sikap, norma subjektif, dan kontrol perilaku. Data penelitian dikumpulkan dari 400 mahasiswi IPB yang dipilih secara acak sebagai paritisipan, dan staf Serambi Botani. Mahasiswa diminta untuk mengisi kuesioner terstruktur dengan metode self-report sedangkan kepada staf Serambi Botani dilakukan wawancara mengenai produk day cream yang dipasarkan. Hasil penelitian menunjukkan bahwa sikap mahasiswi pada produk day cream rumput laut tergolong cukup baik, namun norma subjektif dan kontrol perilaku tergolong rendah. Dengan demikian, mayoritas mahasiswi IPB tidak berminat membeli produk tersebut.
\end{abstract}

Kata kunci: day cream rumput laut, kontrol perilaku, minat beli, norma subjektif, sikap 


\section{Introduction}

As an archipelagic island country, Indonesia has a sea area which is larger than the land area and holds the potential of outstanding marine waters. One of marine resources that is abundant and widely used due to its excellent benefits is seaweed. Indonesia has the potential of seaweed cultivation with total area reaching around 1.110.900 hectares and approximately 555 species or 45 percent of the seaweed species in the world is living in Indonesia (Ministry of Maritime Affairs and Water, 2013).

One of well-known uses of seaweed today is on beauty products. Seaweed is selected as a raw material for beauty products as stated by Santoso et al. (2004) that seaweed living in Indonesia is a variety with good resistance against free radicals and ultraviolet radiation which can cause skin cancer. It is then used by Dr. Ir. Linawati Hardjito, MSc, one of the academics of Bogor Agricultural University (IPB), to conduct research and develop seaweed extracts as natural based beauty products that have been clinically tested and it is good for the skin. Seaweed is then made into various kinds of personal care and marketed at Serambi Botani. An outlet for innovation work product of IPB scattered throughout Indonesia. According to Dwiko Gunawan from Serambi Botani Bogor, day cream made from raw seaweed is recognized as one of the most desirable in Serambi Botani Bogor.

Seaweed day cream product is expected to increase buying interest especially of IPB female students prioritizing facial skin health from natural nutrition. IPB female students as part of the academic community are allegedly to know and willing to buy such products as a result of the innovations developed by faculty. Buying intention is built on three main components, namely attitude, subjective norm, and perceived behavioral control (Ajzen, 1991), and all these components are part of the Theory of Planned Behavior (TPB). Phuong (2011) has proved that all components of TPB had positive influence on buying intention of cosmetics in Vietnam. However, the study did not miss the consideration of diverse student and family characteristics that can also allegedly affect interest in buying the product (Yuliana, 2012).

The study is important to consider the novelty of seaweed day cream at Serambi Botani which requires input information of public interest in buying products especially women as the main target market of this product. The study was conducted to analyze the buying intention of seaweed day cream product with the approach of the Theory of Planned Behavior (TPB). The specific objectives of this study were: (1) to identify the attitude, subjective norm, perceived behavioral control, and female students intention to buy seaweed day cream, (2) to analyze the relationship among variables, and (3) to analyze the influence of the characteristics of student and family, attitude, subjective norm, and perceived behavioral control on the interest to buy seaweed day cream.

\section{Literature Review}

Buying intention is part of the conative components, that is, a person's tendency to carry out an action and behavior in a certain way to an object (Prasetijo and Ihalauw, 2005). The three variables of Theory of Planned Behavior (TPB); the attitude, subjective norm, and perceived behavioral control are used as a tool to measure the buying intention (Ajzen, 2006). Theory of Planned Behavior is the extended of the Theory of Reasoned Action as an attempt to understand social behavior by adding perceived behavioral control as a predictor of intention and behavior (Ajzen, 2012). TPB explains that the better the attitude, subjective norm, and perceived behavioral control on a product, the more encouragement to make purchases. This assumption is in accordance with Ajzen 
(1991) who stated that the better one's attitude and subjective norm as well as perceived behavioral control, the stronger he would consider his intention into a specific behavior.

Nasri and Charfeddine (2012) in his study reveal that attitude, subjective norms, and perceived behavioral control affect the intention to use internet banking in Tunisia. Similar results have been shown by the study of Phuong (2011) in Taiwan on buying intention of cosmetic products. In addition, Hansen et al. (2004) showed that positive attitude, subjective norm, and perceived behavioral control of someone will raise the intention to do online shopping in Denmark.

Theory of Planned Behavior is allegedly associated with individual characteristics (age, hometown, and allowance) and family characteristics (parental age, length of parental study, parental occupation, family income, and family size). Yuliana (2012) revealed that the length of parental study was associated with the subjective norm while the age and allowance were related to perceived behavioral control. Putri (2012) also showed that individual characteristics, such as age, and family characteristics, such as family size and family income were related to attitude, subjective norms, and perceived behavioral control of red rice purchases. In addition, we expect that the characteristics of individual and family may predict buying intention. Some of the factors that influence purchases are age, hometown (Sukmaningtyas, 2012; Setianti, 2012), and allowance (Istikhomah, 2013). Sumarwan (2011) also suggests that hometown will influence one's consumption patterns.

\section{Participants}

\section{Method}

The study used cross sectional design study which was intended to examine aspects of consumer behavior using a relatively short time (Setiadi, 2010). The study was taken place at Bogor Agricultural University (IPB), Dramaga Campus, West Java, Indonesia. The location was chosen purposively as IPB is a higher education institution that conducts research on seaweed which has been developed as skin care products such as day cream. The samples of the study were 400 female students who know information about the product of seaweed day cream and have not made any purchase. They were chosen randomly from the population of 4115 female IPB undergraduate students at the first and second year. Slovin's formula was used for this purpose, as follows.

Where:

$$
\mathrm{n}=\frac{N}{\left(1+N e^{2}\right)}=\frac{4115}{\left(1+4115(0.05)^{2}\right)}=365 \approx 400
$$

$\mathrm{n}=$ sample size

$\mathrm{N}=$ population size

$e=$ error tolerance of 0.05

$1=$ constant value

The samples were also chosen proportionally from faculties of IPB as the subpopulation based on the following formula. The number sample of each subpopulation is shown in Table 1.

$$
\mathrm{ni}=\frac{\mathrm{Ni}}{\mathrm{N}} \times \mathrm{n}
$$


Where:

ni $=$ number of sample from each subpopulation

$\mathrm{Ni}=$ total subpopulation

$\mathrm{N}=$ total population

$\mathrm{n}=$ number of taken sample

Table 1 Number of samples in each subpopulation

\begin{tabular}{lccc}
\hline Name of faculty & Total subpopulation (Ni) & $\begin{array}{c}\text { Number of sample } \\
\text { (ni) }\end{array}$ & $\%$ \\
\hline Agriculture & 507 & 49 & 12 \\
Veterinary & 196 & 19 & 5 \\
Fisheries and Marine Sciences & 414 & 40 & 10 \\
Animal Science & 183 & 18 & 4 \\
Forestry & 426 & 41 & 10 \\
Food Technology & 360 & 35 & 9 \\
Mathematics and Natural & 800 & 78 & 20 \\
Sciences & & & 17 \\
Economics and Management & 693 & 68 & 13 \\
Human Ecology & 536 & 52 & 100 \\
\hline Total & 4115 & 400 & \\
\hline
\end{tabular}

\section{Measures}

The study gathered two types of data, primary and secondary data. Primary data included the characteristics of students and family, TPB dimensions (attitude, subjective norm, and perceived behavioral control), and buying intention which was obtained through a set of self-reported questionnaire. Besides, interview with IPB lecturer who developed the seaweed day cream product and the office staff of Serambi Botani Bogor was also done. Meanwhile, secondary data came from various sources including the number of active students from the Directorate of Educational Administration Bachelor of IPB, data of IPB innovation products at Serambi Botani, as well as library materials from books, the Internet, and journals.

The collection of data was done after the preliminary study involving 30 IPB students to test the reliability and validity of the questionnaire. This was resulted in some invalid question items that required revising. Afterwards, the study was continued with the revised questionnaire involving 370 other female students and 30 students from the preliminary study.

Questionnaires of attitude, subjective norm, and perceived behavioral control were developed from Ajzen (2006) and Yuliana (2011). Attitude consisted of 10 questions of behavioral beliefs and outcome evaluation with the Cronbach's alpha of 0.815. Subjective norm consisted of four statements of normative beliefs and four questions of motivation to comply with the Cronbach's alpha of 0.801 . Perceived behavioral control was measured through six questions of belief control and six questions of control power with the Cronbach's alpha of 0.819 . Questionnaire of buying intention was developed from Fitri (2012), Sudiyanti (2009), dan Yuliana (2012) had Cronbach's alpha of 0.843.

Items on each questionnaire were rated on a 5-point Likert scale. The obtained score was classified into 3 categories in order to ease the data interpretation. For attitude, the categories were good (score 170-250), fair (score 90-169), and poor (10-89). Similarly, subjective norms were categorized as good 
(score 69-100), fair (score 37-68), and poor (score 4-36). The same thing was applied on perceived behavioral control that were categorized as good (score 86125), fair (score 46-85), and poor (score 5-45). Conversely, buying intention was identified into interested in buying the product (score 9-15) or not interested in buying the product (3-8). The categorization was determined by the following formula of interval class:

$$
\text { Class interval }(I)=\frac{\text { maximum score }(N T)-\text { mininum score }(N R)}{\text { number of class }}
$$

Where the category is as follows:

Poor : (NR) to $(\mathrm{NR}+\mathrm{I})$

Fair $\quad:(\mathrm{NR}+\mathrm{I})+1$ to $(\mathrm{NR}+2 \mathrm{I})$

Good : $(\mathrm{NR}+2 \mathrm{I})+1$ to $(\mathrm{NT})$

\section{Analysis}

The collected data underwent a process of editing, coding, scoring, data entering, data cleaning, and data analysis. The data were analyzed by descriptive and inferential statistics using Microsoft Excel and SPSS (Statistical Product and Service Solution). The descriptive analysis was used to describe the characteristics of the sample (age, hometown, and allowance), the characteristics of the family (parental age, length of parental study, parental occupation, family income, and family size), TPB components (attitude, subjective norm, and perceived behavioral control), as well as buying intention. The data were then presented in the form of average value, standard deviation, maximum value, and minimum value.

The inferential analysis used included correlation and regression tests. Pearson correlation test was used to determine the relationships between variables. Chi-Square correlation test was also used for nominal variables, such as hometown area and parental occupation. Multiple linear regression test was conducted to analyze the factors that predicted the intention to buy seaweed day cream.

\section{Results}

\section{Product Overview of Seaweed Day Cream}

Various products have been produced and developed by IPB. The products, food and non-food products, were then commercialized. Day cream product made from seaweed is one of the IPB non-food products which include personal care categories sold at Serambi Botani. The product is a result of the development of seaweed extract research conducted by one of the academics of IPB and has been commercialized by CV Ocean Fresh. The product is sold at Serambi Botani in packs of 30 grams at a price of $\mathrm{Rp} 98.000$. Comprising natural materials, this product offers the benefits of moisturizing the skin from seaweed extract, skin regeneration from chitosan, antioxidant from sea pandan, and mangrove seed extract for sun protection. 


\section{Student and Family Characteristics}

Most students (98\%) were categorized as late teenager with the average age of 20 years old (Hurlock, 1980). The distribution of students hometown region showed that the student dominating came from West Java and Banten $(28.8 \%)$ and there were two female tudents from abroad (Malaysia and Vietnam). The average allowance was Rp 877.325 and more than half of students $(65.8 \%)$ received it from parents (Table 2). Majority of students (95\%) was coming from non-poor family (SI, 2013).

Table 2 Demographic characteristics of students and families

\begin{tabular}{lcc}
\hline Variable & Min-Max & Mean \pm SD \\
\hline Age (year) & $18-24$ & $19.9 \pm 0.8$ \\
Allowance (Rp) & $300.000-4.000 .000$ & $877.325 \pm 373.271$ \\
Father's age (years old) & $39-70$ & $47 \pm 14.3$ \\
Mother' age (years old) & $35-62$ & $46.2 \pm 7.1$ \\
Father's length of study (year) & $3-21$ & $13.6 \pm 3.3$ \\
Mother's length of study (year) & $3-21$ & $12.8 \pm 3.4$ \\
Family monthly income (Rp) & $850.000-35.000 .000$ & $4.879 .500 \pm 3.587 .898$ \\
Family monthly income per capita & $150.000-8.750 .000$ & $1.061 .817 .26 \pm 815.942 .36$ \\
(Rp) & & $4.8 \pm 1.3$ \\
Family size (person) & $2-10$ & \\
\hline
\end{tabular}

Consumers interact with their surroundings, including the family (Sumarwan, 2011). Referring to the age categorization by Hurlock (1980), the age of both parents of students was classified as middle-aged (87.8\%). In general, the latest education undertaken by both parents was high school $(35.5 \%)$. Parental occupations varied between fathers and mothers. Fathers' occupations were more dominating on the civil servant (38.5\%) and mothers' were housewives $(55 \%)$ with the average family income of Rp 4.879.500 applied for about five members and had included the allowance allocation. The monthly income per capita was around one million, indicating that the vast Theory of Planned Behavior Approach

Attitude. Attitude forms beliefs about the object and links it to the specified attribute that is to other objects and characteristics of an event (Ajzen, 1991). Peter and Olson (2010) categorize attitude into two components, namely the belief that the behavior will produce an output or beliefs of the consequences for doing the behavior (behavioral beliefs), and the evaluation of the consequences of the trust (outcomes evaluation). Hence, female students (74\%) showed a fair attitude on the seaweed day cream product (Table 3). Students fairly believe that the seaweed day cream may give them healthy facial skin (47\%) and may have better quality than that of similar non-IPB products $(47 \%)$, thus they will not need any other products as the natural ingredients are sufficient for their facial health $(56.5 \%)$. However, they are possibly dependent on the product $(43.5 \%)$ and get allergic reaction because of the sea-based ingredient $(49.5 \%)$.

Subjective norms. Subjective norms related to normative beliefs of a person to make another person a role model in performing a particular behavior (Fishbein and Ajzen, 1975). Subjective norm is formed by two components: normative beliefs and motivation to comply (Sumarwan, 2011). More than half of students 
showed a poor level of subjective norm on seaweed day cream product $(60.8 \%)$ (Table 3 ). They are suggested to purchase seaweed day cream product mostly by classmate $(43.5 \%)$ and will care for complying the suggestion (52\%).

Perceived behavioral control. Perceived behavioral control is perceived by a group of individuals in their ability to perform certain behaviors (Ajzen, 2006). This construct is formed by two components: 1) the strength of one's belief that he can do something (control beliefs), and one's belief of the existence of barriers or supports to perform a behavior (power of control). Female students had less perceived behavioral control on seaweed day cream product (73\%) (Table 3). Students believe that they mostly have a fair power constraint to buy seaweed day cream product (55\%), thus they do not have power of control over it.

\section{Buying Intention}

Buying intention is part of the conative component, that is, a person's tendency to perform an act or behavior in a certain way to an object (Prasetijo and Ihalauw, 2005). According to Sumarwan (2004), connative is the third component of the attitude on consumer research that reveals the consumer desire to purchase (intention to buy). The study showed that students were not interested in purchasing the seaweed day cream product (75.2\%) (Table 3). Most of students constantly disagree to purchase $(55.4 \%)$ and to use $(53.9 \%)$ the product within a month later as well as substitute their current day cream with seaweed day cream product manufactured by IPB $(61.5 \%)$.

Table 3 Distribution of students by categories of attitude, subjective norm, perceived behavioral control, and buying intention

\begin{tabular}{lcc}
\hline Category & $\mathrm{N}$ & $\%$ \\
\hline Attitude & 40 & 10.0 \\
Poor (score 10-89) & 296 & 74.0 \\
Fair (score 90-169) & 64 & 16.0 \\
Good (score 170-250) & & \\
Subjective norm & 243 & 60.8 \\
Poor (score 4-36) & 149 & 37.2 \\
Fair (score 37-68) & 8 & 2.0 \\
Good (score 69-100) & 292 & \\
Perceived behavioral control & 101 & 73.0 \\
Poor (score 5-45) & 7 & 25.2 \\
Fair (score 46-85) & & 1.8 \\
Good (score 86-125) & 301 & 75.2 \\
Buying intention & 99 & 24.8 \\
Not interested in buying the product (score 3-8) & 400 & 100.0 \\
Interested in buying the product (score 9-15) & & \\
Total & &
\end{tabular}

\section{Relationships between Variables}

Table 4 shows the results of correlation analysis that the hometown has a significant positive relationship with attitude $(\mathrm{r}=0.001 ; \mathrm{p}<0.01)$ and purchase intention $(r=0.046 ; p<0.05)$. This indicates that the student who comes from the area of Bogor has a positive attitude and a high buying intention on the seaweed day cream. 
Individual characteristics were not related significantly to any of Theory of Planned Behavior components and the intention to buy. Similarly, the characteristics of the family showed no significant correlations with attitude, subjective norms, and perceived behavioral control of students unless mother's occupation which correlating significantly with buying intention $(r=0.024 ; \mathrm{p}<0.05)$. Thus, highly buying intention on the seaweed day cream product is shown by a female student with a working mother. Buying intention was shown to be associated with all three TPB components: attitude $(\mathrm{r}=0.199 ; \mathrm{p}<0.000)$, subjective norms $(\mathrm{r}=0.170 ; \mathrm{p}<0.001)$, and perceived behavioral control $(\mathrm{r}=0.197 ; \mathrm{p}<0.000)$. This implies that the better attitude, subjective norm, and perceived behavioral control of students, the higher the intention to buy the seaweed day cream product.

Table 4 Correlation analysis between variables (Chi-Square and Pearson correlation coefficient)

\begin{tabular}{|c|c|c|c|c|}
\hline Variable & Attitude & $\begin{array}{c}\text { Subjective } \\
\text { norm }\end{array}$ & $\begin{array}{c}\text { Perceived } \\
\text { behavioral control }\end{array}$ & $\begin{array}{l}\text { Buying } \\
\text { intention }\end{array}$ \\
\hline $\mathrm{Age}^{2}$ & 0.009 & 0.088 & 0.012 & 0.033 \\
\hline Hometown ${ }^{1}$ & $0.001 * *$ & 0.393 & 0.589 & $0.046 *$ \\
\hline Allowance $^{2}$ & 0.008 & 0.065 & 0.001 & -0.088 \\
\hline Father's age ${ }^{2}$ & -0.006 & -0.063 & 0.011 & 0.051 \\
\hline Mother's age ${ }^{2}$ & 0.071 & 0.024 & 0.056 & 0.026 \\
\hline Father's length of study ${ }^{2}$ & -0.007 & 0.034 & -0.064 & 0.047 \\
\hline Mother's length of study ${ }^{2}$ & -0.041 & 0.052 & -0.027 & 0.040 \\
\hline Father's occupation ${ }^{1}$ & 0.503 & 0.871 & 0.894 & 0.363 \\
\hline Mother's occupation ${ }^{1}$ & 0.946 & 0.409 & 0.279 & 0.024* \\
\hline $\begin{array}{l}\text { Family monthly income per } \\
\text { capita }^{2}\end{array}$ & 0.009 & 0.018 & 0.009 & -0.004 \\
\hline Family size $^{2}$ & 0.029 & -0.084 & 0.038 & 0.057 \\
\hline Attitude $^{2}$ & - & - & - & $0.199 * *$ \\
\hline Subjective norm ${ }^{2}$ & - & - & - & $0.170 * *$ \\
\hline $\begin{array}{l}\text { Perceived behavioral } \\
\text { control }^{2}\end{array}$ & - & - & - & $0.197 * *$ \\
\hline $\begin{array}{l}\text { Note. }{ }^{\mathrm{I}} \text { Chi-Square test }(\mathrm{p}-\mathrm{v} \\
{ }^{2} \text { Pearson correlation test }\end{array}$ & $\begin{array}{l}(* *) \\
(*)\end{array}$ & $\begin{array}{l}\text { ant at } \\
\text { ant at } \\
\text { ant }\end{array}$ & $\begin{array}{l}e<0.01 \text { (2-tailed) } \\
e<0.05 \text { (2-tailed) }\end{array}$ & \\
\hline
\end{tabular}

\section{Factors that Predict Buying Intention}

The results of multiple linear regression tests as shown in Table 5 indicate that on the regression model suggested in this study, the independent variables contribute as big as 8.1 percent on the intention to buy the seaweed day cream product while the rest is explained by other variables excluded this study. The study proves that the components of the Theory of Planned Behavior (attitudes, subjective norms, and perceived behavioral control) predict buying intention. Meanwhile, the notion that the individual characteristics and family characteristics influence buying intentions are not evident in the study except that only a few aspects, such as hometown and mother's employment status.

Attitude, subjective norm, and perceived behavioral control predicted an increasing of buying intention score as big as 0.009, 0.018, and 0.008, respectively. Thus, positive attitude, recommendation from many reference groups and/or social groups to comply, as well as less constraint and good control over it will contribute to the increasing of buying intention of students. Meanwhile, hometown and mother's employment status were more likely to alter buying 
intention score positively by 0.490 and 0.481 points. Students from Bogor will be more likely to have high intention to buy the seaweed day cream product compared to other regions. Likewise, students who have a working mother will also increase the probability to buy the seaweed day cream product.

Table 5 Results of multiple linear regression analysis of factors that predict buying intention on seaweed day cream

\begin{tabular}{|c|c|c|c|}
\hline \multirow[t]{2}{*}{ Variable } & $\begin{array}{c}\text { Unstandardized } \\
\text { coefficient }\end{array}$ & $\begin{array}{c}\text { Standardized } \\
\text { coefficient }\end{array}$ & \multirow[t]{2}{*}{ Sig. } \\
\hline & $\mathrm{B}$ & $B$ & \\
\hline Constant & 3.274 & & 0.139 \\
\hline Age (year) & 0.055 & 0.025 & 0.613 \\
\hline Hometown $(1=$ Bogor, $0=$ non Bogor $)$ & 0.490 & 0.099 & $0.043 *$ \\
\hline Allowance (Rp) & $-6.072 \mathrm{E}-7$ & -0.126 & 0.050 \\
\hline Age of father (year) & 0.001 & 0.011 & 0.830 \\
\hline Mother's length of study (year) & 0.051 & 0.096 & 0.075 \\
\hline Mother's occupation & 0.481 & 0.133 & 0.013* \\
\hline Family monthly income (Rp) & $1.295 \mathrm{E}-7$ & 0.059 & 0.377 \\
\hline Family size & 0.077 & 0.054 & 0.294 \\
\hline Attitude (score) & 0.009 & 0.174 & $0.000 * *$ \\
\hline Subjective norm (score) & 0.018 & 0.149 & $0.003 * *$ \\
\hline Perceived behavioral control (score) & 0.008 & 0.169 & $0.000 * *$ \\
\hline F & & 4.200 & \\
\hline Adjusted $\mathrm{R}^{2}$ & & 0.081 & \\
\hline Sig & & 0.000 & \\
\hline
\end{tabular}

\section{Discussion}

Family members are of a purchasing organization that can greatly affect consumer buying behavior (Kotler and Armstrong, 2006). Female student is part of the family members who are influential in the purchase, especially for her personal care products. The results showed that the majority of female students (70\%) had a special attention to the facial skin so that they use a facial cream to make the skin much healthier. Face cream (day cream) mostly used (69.9\%) is a drugstore product that has been sold widely in the market. However, a wide variety of brands discourages the student from the exposure of seaweed day cream products, the innovative personal care product developed by IPB. It proved that almost all female students $(84.5 \%)$ did not know the existence of the product.

On the other hand, more than half of female students $(52.2 \%)$ expressed an interest in the benefits of the seaweed day cream product, such as having healthy and clean skin, as well as the antioxidants. As noted by Frewer et al. (1996), beliefs about the risks and benefits are of capital importance to determine the attitude. It is then behind the fair attitude of students to use seaweed day cream product (74\%). Consumers' attitude will indeed influence their buying behavior, depending on various factors that hinder and reinforce the intention and their behavior, but out of those things, consumers personality are the most important factors (Sudiyanti, 2009).

The findings revealed that there were female IPB students $(19.8 \%)$ who did not know the food and non-food products produced by the IPB academics and 
mass market assisted by IPB, including being not knowing the seaweed day cream marketed at Serambi Botani. Students who did not know the product almost entirely $(91.1 \%)$ revealed a lack of information obtained, as well as less recommendation from friends and family. The closest person is part of the subjective norm; the reference group/role models as consideration to perform or not a particular behavior (Fishbein and Ajzen, 1975). Nearly half of female students $(47.8 \%)$ believed that friends are the most important sources of information related to IPB products included the seaweed day cream. Friends around the consumer become a source of personal information that can define and reinforce to make a purchase (Kotler and Keller, 2008). In general, even though the student has a role model in her immediate environment, differences of opinion and taste of the product is normal (Yuliana, 2011). Therefore, female students in the study had poor subjective norm $(60.8 \%)$. Furthermore, students also had less behavioral control $(73 \%)$. They considered that the obstacles that may be encountered when buying the product can be anticipated.

Generally, all components from the Theory of Planned Behavior - attitude, subjective norm, and perceived behavioral control were not good. Thus, student's buying intention was classified in the low category. Ajzen (1991) states that the better the person's attitude and subjective norm as well as the bigger the perceived behavioral control, the stronger a person would consider his intention into a specific behavior. Students' concerns that the seaweed day cream will not be suitable for their face in which they are afraid to use it is another thing that discourage them from doing the purchase. Besides, the students showed a loyalty over their current product that they are not interested in switching into the seaweed day cream. Moreover, female students (75.2\%) are not interested in buying the product due to its unpopularity.

The test results showed that out of all TPB components, attitude was proved to be associated with hometown. The hometown was divided into Bogor regions and non-Bogor regions. The findings indicate that students from Bogor regions have a good attitude on the seaweed day cream product. Schiffman and Kanuk (2004) reveal that the attitude is the tendency of learning related to the buying behavior as a result of direct experience with the product, word of mouth information obtained from other people or mass media exposure, and direct product exposure. Students coming from Bogor area who certainly have the experience and information about the seaweed day cream product sold at Serambi Botani are much greater than students from outside Bogor; thus, this makes their attitude much better as well.

Buying intention had a significant positive relationship with attitude, subjective norm, and perceived behavioral control. In accordance with the research of Phuong (2011), all components of TPB have a significant and positive relationship with buying intention of cosmetic products. Thus, attitude, subjective norm, and students' perceived behavioral control will be more likely to increase the intention to buy the seaweed day cream product. Besides those components, hometown and mother's employment status have a significant positive relationship with buying intention. However, the findings are not consistent with Yuliana (2012) who said that the hometown does not have a relationship with 
buying intention as well as Istikhomah (2013) who said that mothers' occupation is not associated with the intention to buy IPB food products.

The results of the regression test showed that the three components of TPB as well as hometown and mother's employment status predicted the increasing of students' buying intention on the seaweed day cream product. Similarly, Sudiyanti (2009) has proved that attitude, subjective norm, and perceived behavioral control have a significant positive effect on the interest in buying healthy food products. In addition, the study is also consistent with the study of Setianti (2012) saying that the hometown affects the buying intention on batik clothing. This may happen as consumers who live close to the product will be more easily to obtain the information directly and more encouraging them to do the purchase. Meanwhile, Kotler and Armstrong (2006) have revealed that one's occupation affects his buying intention on goods and services. The same thing occurs on female students since most of them are still financed by parents. Hence, working mothers who help meet the needs of family will be more likely to afford her daughter's personal care products compared to those who is not working.

\section{Conclusion}

\section{Conclusion and Recommendation}

All components of Theory of Planned Behavior (TPB) (attitude, subjective norm, and perceived behavioral control) show different outcome on the seaweed day cream product. The attitude on the seaweed day cream product is fair, yet the subjective norm and perceived behavioral control are poor. This may predict students intention and behavior not to buy the product. Students from Bogor will be more likely to have better attitude on the product as they live close to where the product coming. Meanwhile, working mother will be more able to care and afford her daughter's personal care. Hence, students with working mother will be more likely to buy the product.

\section{Recommendation}

Socialization variety of food and non-food products, especially the seaweed day cream needs to be increased by IPB through in and off campus events. It is expected to increase the awareness of IPB academics as well as society as a whole who have not yet heard of various products of IPB. Promotion is also required by manufacturers or Serambi Botani to attract consumers, especially female students to increasingly interested in buying IPB products. In addition, consumers are also expected to find information about the various beauty products, one of which is seaweed day cream, to keep them informed of its benefits for the skin. Suggestions for further research are to involve lecturers and other academics of IPB in a questionnaire to determine their intention to buy IPB products particularly seaweed day cream product. In addition, improvement is needed for further research by doing a deal before conducting the data collection by equalizing the basic information presented to respondents before filling out. If the questionnaire is done by self report, charging contacts need to be included in the questionnaire in order to facilitate the respondents who have difficulties in filling out the questionnaire. 


\section{Reference}

Ajzen, I. (1985). From intentions to actions: A theory of planned behavior. Action control: From cognitions to behavior, 11-39.

(1991). The theory of planned behavior. Organizational Behavior and Human Decision Processes, 150, 179-211. Retrieved from http://people.umass.edu/aizen/publications.html.

(2006). The theory of planned behavior. Retrieved from http://people.umass.edu/aizen/publications.html. . (2012). The theory of planned behavior. In P. A. M. Lange, A. W. Kruglanski \& E. T. Higgins (Eds.), Handbook of theories of social psychology (Vol. 1, pp. 438-459). London, UK: Sage.

Dwityanti, E. (2008). Analysis of the factors that influence consumer buying interest against Mandiri Internet Banking service [Analysis of the factors that influence consumer buying intention of Mandiri Internet Banking services] (Master's thesis). Retrieved from www.researchgate.net

Fishbein, M, \& Ajzen, I. (1975). Belief, Attitude, Intention, and Behavior: An Introduction to Theory and Research. Reading, MA: Addison-Wesley MA.

Frewer, L. J., Howard, C., Hedderley, D., \& Shepherd, R. (1996). What determines trust in information about food-related risk? Underlying psychological constructs, Risk Analysis, 16, 443-600.

Istikhomah, E. (2013). The influence of the reference group and knowledge of the food product buying interest IPB undergraduates [The influence of the reference group and knowledge on the buying intention of IPB undergraduate students on food product] (Undergraduate thesis). Retrieved from http://repository.ipb.ac.id/bitstream/handle/123456789/63141/I13eis.pdf?seq uence $=1 \&$ is Allowed $=y$.

Kotler, P., \& Armstrong, G. (2006). Principles of Marketing [Principles of Marketing] (12th ed.). Jakarta, Indonesia: Erlanggga.

Kotler, P., \& Keller, K. L. (2008). Marketing Management [Marketing Management] (13th ed.). Jakarta, Indonesia: Erland.

Ministry of Maritime Affairs and Water. (2013). Indonesia increase seaweed production 10 million tons [Indonesian to press seaweed production by 10 million tons]. Retrieved ftom http://www.kkp.go.id/Indonesia-GenjotProduksi-Rumput-Laut.

National Population and Family Planning Board. (1996). Agency for National Family Planning Program Policies [Policy Board of the National Family Planning Program]. Jakarta, Indonesia: Author.

Peter, J. P., \& Olson, J. C. (2010). Consumer Behavior and Marketing Strategy (8th ed). New York, NY: McGraw-Hill.

Phuong, P. T. (2011). An empirical study on consumer intention for cosmetics in Vietnam based on the theory of planned behavior (Master's thesis). Retrieved from http://ir.lib.stu.edu.tw/ir/retrieve/577/stu-100-s977314181 .pdf.

Prasetijo, R., \& Ihalauw, J. J. O. I. (2005). Consumer Behavior [Consumer Behavior]. Yogyakarta, Indonesia: Andi. 
Santoso, J., Yoshiestark, Y., \& Suzuki, T. (2004). Anti-oxidant activity of methanol extracts from Indonesian seaweeds in an oil emulsion models. Journal of Fisheries Science, 70 (1), 183-188. doi: 10.1111 / j.14442906.2003.00787.x

Schiffman, L. G., \& Kanuk, L. L. (2004). Consumer Behavior (8th ed.). New Jersey, NJ: Pearson Prentice Hall.

Sudiyanti, S. (2009). Predicting women purchase intention for green food products in Indonesia (Master's thesis). Retrieved from https://brage.bibsys.no/xmlui/bitstream/handle/11250/135342/Sudiyanti\%20 Sudiyanti.pdf.

Sumarwan, U. (2004). Consumer Behavior: Theory and Practice in Marketing [Consumer Behavior: Theory and Application in Marketing] (1st ed.). Bogor, Indonesia: PT Ghalia Indonesia.

(2004). Consumer Behavior: Theory and Practice in Marketing [Consumer Behavior: Theory and Application in Marketing] (2nd ed.). Bogor, Indonesia: PT Ghalia Indonesia.I

Yuliana, M. (2012). Analysis of the food product purchase intentions IPB: Approach theory of planned behavior [Analysis of the purchase intentions of IPB food product: Theory of planned behavior approach] (Undergraduate thesis). Bogor, Indonesia: Bogor Agricultural University 